\title{
Germanizmi v frazemih Slovarja slovenskega knjižnega jezika od R do Ž
}

\author{
Irena Stramljič Breznik-Marjana Hameř̌ak
}

Prispevek predstavlja zadnji del raziskave o germanizmih od R do Ž, sprejetih v Slovar slovenskega knjižnega jezika, ki so hkrati tudi frazemske sestavine. Za tovrstne frazeme se na podlagi slovarskih označevalnikov ugotavlja korelacija med zaznamovanostjo germanizma in zaznamovanostjo frazema $\mathrm{z}$ njim, živost in poznavanje frazemov pa se preverjata s pomočjo referenčnega korpusa FidaPLUS in vprašalnika, ki ga je izpolnilo štiriinpetdeset študentov drugega letnika enopredmetnega študija slovenskega jezika na Filozofski fakulteti Univerze v Mariboru.

Ključne besede: slovenščina, leksikologija, frazeologija, frazemi, germanizmi, slovar

\section{Germanisms in idioms in the Slovar slovenskega knjižnega jezika (Standard Slovenian Dictionary) from R to $\check{Z}$}

This article presents the final part of a study (R-Ž) of Germanisms in the Slovar slovenskega knjižnega jezika (Standard Slovenian Dictionary, SSKJ) that are also elements of idioms. Based on their dictionary labels, these idioms are analyzed in terms of correlation between marked Germanism and therefore also marked idiom; however, the contemporary use and knowledge of these idioms were assessed using the FidaPLUS reference corpus and a questionnaire completed by fifty-four second-year students in the single-discipline undergraduate program in Slovenian at the University of Maribor's Faculty of Arts.

Key words: Slovenian, lexicology, phraseology, idioms, Germanisms, dictionary

\section{Uvod}

1.1 Pričujoči prispevek je nadaljevanje in hkrati zaključek raziskave o germanizmih kot sestavinah slovenskih frazemov (Stramljič Breznik 2007: 291-303; 2007a: 459-473; 2009: 63-74). Zaradi primerljivosti rezultatov je ohranjen tudi enak metodološki pristop. Na podlagi potrjenih nemških izposojenk v slovenščini (StriedterTemps 1963) in njihovih razlag v etimoloških slovarjih slovenskega jezika Franceta Bezlaja (1995, 2005) in Marka Snoja (2003) je bila preverjena njihova vključenost $\mathrm{v}$ gradivo SSKJ.

Pri delu sta bili postavljeni dve merili. Upoštevane so samo izposojenke, (a) ki imajo status germanizma, kar pomeni, da niso sprejete v knjižno normo - 
prvi pomen v Enciklopediji slovenskega jezika (Toporišič 1992: 47) - in so zaznamovane $\mathrm{z}$ določenim kvalifikatorjem $\mathrm{v}$ celoti ali pa je tako zaznamovan samo kateri izmed njihovih pomenov, npr. šparati nižje pog. 'varčevati' < srvn. sparen, nvn. sparen (ST: 223; ESSJ IV, 96; SES: 735); prim. tudi Valh Lopert 2007; (b) ki so sestavina frazema $\mathrm{v}$ SSKJ, razporejenega $\mathrm{v}$ frazeološko gnezdo ali zunaj njega. Tako so bile izločene tiste prevzete besede, ki so v slovenski knjižni jezik prišle iz/prek nemščine in so se vanj popolnoma vrasle, čeprav nastopajo kot sestavine v frazemih. Danes spadajo v območje stilno nevtralne leksike in so v SSKJ sprejete brez kakršnega koli kvalifikatorja, npr. škarje (< stvn. skâri, srvn. schœre, schœr, nvn. Schere; ST: 218; ESSJ IV: 53; SES: 728), ura (<nvn. Uhr, srvn. ûre, ûr; ST: 242; ESSJ: 264, SES: 800), žemlja (< srvn. sëmel(e), stvn. sëmala, nvn. Semmel; ST: 250; ESSJ IV: 446; SES: 867) ipd.

1.2 Glede na sedanje aktualno terminološko stanje je uporabljen izraz frazem. Kot definicijske lastnosti frazemov upoštevamo tradicionalna merila: reproduciranost, najmanj dvobesednost (Kržišnik 1994), ki vključuje tudi tip minimalnih frazemov (tj. takih s strukturo glagola in predložnega prostega morfema ali glagola in zaimenskega prostega morfema v klitični obliki (Kržišnik 2005) in tudi t. i. dvojčiče raznih tipov (Toporišič 1996)), neizpeljivost pomena iz pomena sestavin, stalnost in ekspresivnost. V teoretičnem smislu pa sta upoštevana še dognanja o pragmatični frazeologiji (Jakop 2006) in korpusni pristop pri raziskovanju frazeologije v slovenistiki (Gantar 2007).

Vključeni so tudi nekateri primeri pregovorov, ki sicer ne spadajo v ožje področje frazeologije, določeno s prej naštetimi definicijskimi lastnostmi. Pri gradivu frazemov se izhaja iz SSKJ, dopolnilna vira sta poskusni frazeološki slovar (Keber 2003) in korpus slovenskega jezika FidaPLUS.

1.3 Številka v oklepaju pred germanizmom informira o tem, ali leksem kot iztočnica v slovarskem geselskem članku SSKJ vsebuje frazem v predvidenem frazeološkem gnezdu (oznaka pred tako iztočnico je 1), ali iztočnica $v$ svojem geselskem članku vsebuje frazem, vendar ne v ustreznem frazeološkem gnezdu (oznaka pred tako iztočnico je 2), ali je iztočnica brez sicer znanega ali v drugih virih označenega frazema (oznaka pred tako iztočnico je 3). Včasih so zaradi več frazemov z isto sestavino možne tudi kombinacije, označene s poševnico.

V frazeološkem gnezdu SSKJ so pogosto zapisane tudi besedne zveze, ki jih ne prištevamo med frazeme, ker bodisi ne izpolnjujejo merila večbesednosti ali prenesenega pomena, kot kaže naslednji primer: ríhtati -am nedov., nižje pog. 1. 'skrbeti za koga, negovati koga'; 2. 'priskrbovati, oskrbovati' < srvn. rihten, nvn. richten (ST: 211; ESSJ III: 179; SES: 622). Označen frazeološki pomen v SSKJ: - nižje pog. ta človek mi je zoprn, ker vedno koga rihta 'daje komu nauke, se vmešava v njegovo ravnanje, vedenje'; nižje pog. ulilo se je, ravno ko je rihtala otroka za v šolo 'odpravljala otroka v šolo'; nižje pog. mlada dva zdaj rihtata stanovanje 'urejata stanovanje'. Zveza rihtati koga 'dajati komu nauke, se vmešavati v njegovo ravnanje, vedenje' ne spada med frazeme, ker ne izpolnjuje kriterija večbesednosti. Besedni zvezi rihtati otroka za v šolo 'odpravljati otroka $\mathrm{v}$ šolo' in rihtati 
stanovanje 'urejati stanovanje' ne spadata med frazeološke zveze, saj je pomen teh zvez predvidljiv iz pomena posameznih sestavin, torej ne gre za frazeološki pomen. Bodisi so v okviru frazeološkega gnezda navedene stalne, tj. (pol)terminološke besedne zveze, kot v naslednjem primeru: špíca ${ }^{2}$-e ž 1. pog. 'zelo zožen, priostren končni del česa; konica'; 2. publ. 'čas, ko se kaj pojavlja v najvišji meri, stopnji; konica’ < nvn. Spitze (ST: 224; ESSJ IV: 99; SES: 737). Označen frazeološki pomen v SSKJ: • [...] žarg., film. (filmska) špica 'začetni del filmskega traku s podatki o filmu; filmska glava'; žarg., film. stalna špica 'avdiovizualni uvod h kaki redno ponavljajoči se televizijski oddaji’. Zato so tovrstni primeri izločeni iz obravnave.

1.4 Germanizmi so zapisani po abecedi od $\mathrm{R}$ do $\breve{Z}$ tako, da je najprej označen tip iztočnice glede na vsebovanost frazema v SSKJ. Iztočnica je izpisana z malimi tiskanimi črkami, dodane ima osnovne slovnične lastnosti, nato pa je prikazana prevzetost iz nemščine na podlagi tujih in domačih etimoloških virov. Potem so pripisana kvalifikatorska pojasnila in ponazarjalno gradivo ter ustrezno frazeološko gnezdo s frazemom, po potrebi pa je dodan morebitni manjkajoči frazem. Frazemi so vključno z vezljivostnimi mesti zapisani ležeče in krepko. Znak / ločuje variantno sestavino frazema, okrogli oklepaj ( ) pa sestavino, ki jo lahko izpustimo. Sledijo podatki o pojavitvah v korpusu slovenskega jezika FidaPLUS s pripadajočimi zgledi. Če ni posebnosti ali variantnosti, je navadno zabeležen le en zgled rabe.

\section{$2 \quad$ Abecedni prikaz}

(1) rájda -e ž nižje pog. 'vrsta' < srvn. *rîde, stvn. *rîda, srvn. rîden (ST: 206; ESSJ III: 178; SES: 621).

Označen frazeološki pomen v SSKJ: • ekspr. $v$ vasi je cela rajda gostiln 'veliko gostiln'. $\mathrm{F}+$ : cela rajda (22 pojavitev), zgled: Takoj za njim se je zvrstila cela rajda ansamblov.

(1/3) rájža -e ž star. 'potovanje' < srvn. reise, reisen, nvn. Reise, reisen (ST: 207; ESSJ III: 147; SES: 600).

Označen frazeološki pomen v SSKJ: • star. še nobeno rajžo niso bili tako prijazni kot danes 'nobenkrat'.

Neoznačen frazeološki pomen v SSKJ: iti na rajžo 'potovati'.

$\mathrm{F}+$ : nobena rajža (0 pojavitev).

F+: iti na rajžo (20 pojavitev); zgled: Tu se res splača iti na rajžo, to je tudi Trdina dobro vedel.

$(1 / 2)$ regimènt -ênta $m$ 1. star. 'polk, poveljnik, štab regimenta / pehotni regiment'; 2. ekspr., z rodilnikom 'velika količina, množina' < nvn. Regiment (ST: 209; SES: 612).

Označen frazeološki pomen v SSKJ: • star. sedemnajsti regiment v stari Avstriji 'pehotni polk, v katerem služijo vojsko vojaki iz Kranjske'.

Neoznačen frazeološki pomen v SSKJ: dobiti cel regiment nasvetov 'veliko količino'.

$\mathrm{F}+$ : sedemnajsti regiment $v$ stari Avstriji (0 pojavitev).

$\mathrm{F}+$ : cel regiment (16 pojavitev); zgled: Vojvoda je menil, da je na graščini dovolj prostora za cel regiment majhnih dečkov ... 
- (2) ríhta ${ }^{1}$-e ž 2. star. 'sojenje, sodni proces' < rihtati 'richten (als Richter)' < srvn. richten 'Recht sprechen, richten’; nvn. richten (ST: 211; ESSJ III: 179; SES: 622)

Neoznačen frazeološki pomen v SSKJ: krvava rihta

$\mathrm{F}+$ : krvava rihta (45 pojavitev); zgled: Šestdeseta obletnica naše osvoboditve in krvave rihte, ki jo je le-ta prinesla s sabo ...

(1) ríhta ${ }^{2}$-e ž nižje pog. 'ena ali več jedi, zlasti kuhanih, ki tvorijo samostojen del v okviru enega obroka' < Gericht 'eine Speise' < srvn. rihte, riht 'angerichtete Speise'; nvn. Gericht (ST: 211; ESSJ III: 179; SES: 622).

Označen frazeološki pomen v SSKJ: • pog., ekspr. ta človek je pokrita rihta 'ne kaže svojih negativnih lastnosti'.

F+: (biti) pokrita rihta (4 pojavitve); zgled: Ni bil več kot pokrita rihta, zdaj sta si bila končno enakopravna in podobna kot ...

(1) ròm rôma m nižje pog. "priprava iz lesa ali drugega materiala, ki obdaja sliko ali druge predmete'; 'okvir' < bav. avstr. die Rahm, srvn. ram, rame, nvn. Rahmen (ST: 212; ESSJ III: 195; SES: 628).

Označen frazeološki pomen v SSKJ: • pog. ta je pa za v rom 'zelo je lepa'.

$\mathrm{F}+$ : (biti) za $v$ rom (0 pojavitev).

(1) šláger-ja m zastar. 'popevka' < nvn. Schlager (ST: 218).

Označen frazeološki pomen v SSKJ: • publ. najnovejši časopisni šlager 'pogosto ponavljana aktualna tema'; publ. film je postal šlager leta, sezone 'najbolj uspešen film'.

$\mathrm{F}+$ : časopisni šlager (0 pojavitev).

$\mathrm{F}+$ : šlager leta (3 pojavitve); šlager sezone (11 pojavitev); zgled: A ker je znano, da so skoraj nerabljene Octavie izvozni šlager (letošnjega) leta, je Škodin tržni delež malce prenapihnjen. Vedel je tudi, da je svetu podaril nekaj novega: arijo uspešnico, tako rekoč šlager sezone. Pojavi se tudi varianta šlager stoletja (1 pojavitev); zgled: Za prvo menim, da bo v bistvenih pogledih rešena $v$ kakih dvajsetih letih, a druga bo nedvomno šlager (celotnega) stoletja, če ne daljšse dobe.

(2) šlápa -e ž 1. nav. mn., nižje pog. 'obrabljena, ponošena copata': stare šlape na bosih nogah; 2. slabš. 'neodločen, bojazljiv človek' < nvn. Schlapp(en) (ST: 220; ESSJ IV: 80; SES: 732).

Neoznačen frazeološki pomen v SSKJ: njen možje šlapa 'omahljiv, ženi podložen mož'. $\mathrm{F}+$ : biti šlapa (1 pojavitev); zgled: ... da se Benjamin spreminja in da postaja možakar in ni več šlapa.

(1) ̌nófati -am nedov., nižje pog. 1. 'vohati, duhati'; 2. 'poizvedovati, povpraševati' < srvn. bav. *snopfen, srvn. snupfen, srvn. bav. *snopf(e), srvn. snupf(e) (ST: 221; SES: 733). Označen frazeološki pomen v SSKJ: • nižje pog. šnofati tobak 'njuhati'.

F+: šnofati tobak (0 pojavitev). Varianta: šnofati hors (1 pojavitev); zgled: Kadijo pa šnofajo hors, totalno stran metanje ...

(1) špárati -am nedov., nižje pog. 'varčevati' < srvn. sparen, nvn. sparen (ST: 223; ESSJ IV: 96; SES: 735).

Označen frazeološki pomen v SSKJ: • nižje pog. tega fanta doma šparajo 'mu ne nalagajo (težkega) dela' '; nižje pog. pri delu se špara 'ni delaven'; kdor jezika špara, kruha

V frazeološkem gnezdu je zabeležena besedna zveza šparati koga 'ne nalagati mu (težkega) dela', ki je ne prištevamo med frazeme, ker ne izpolnjuje kriterija večbesednosti. 
strada 'kdor si ne upa, ne zna kaj vprašati, prositi, ima škodo, ne doseže tistega, za kar se poteguje'.

$\mathrm{F}+$ : šparati se pri delu (0 pojavitev).

$\mathrm{F}+$ : kdor jezika špara, kruha strada (15 pojavitev); zgled: Pravijo tudi, da kdor jezik špara, kruha strada. Varianta: kdor besede špara, kruha strada (1 pojavitev); zgled: Kdor besede špara, kruha strada, pravi pregovor.

(1) ̌̌́ás -a m nižje pog. 'neresen, smešen ali zabaven dogodek; šala, potegavščina' < nvn. Spaß (ST: 223; ESSJ IV: 96; SES: 736).

Označen frazeološki pomen v SSKJ: • pog., ekspr. to narediti, je zame špas 'malenkost'; pog., ekspr. taka hrana je drag špas 'veliko stane'; pog., ekspr. z njim smo imeli zmeraj velik špas 'smo se šalili'; nižje pog. ona ni za špase 'je resna, ne mara potegavščin'.

$\mathrm{F}+$ : biti kaj špas (0 pojavitev).

F+: biti kaj drag špas (30 pojavitev); zgled: Umetniška dela pri Slovencih veljajo za drag špas.

$\mathrm{F}+$ : biti kaj velik špas (2 pojavitvi); zgled: To jim je največji špas, kar si ga lahko zamislijo $\mathrm{F}+$ : ne biti za špase (0 pojavitev).

(1/2) špèh špêha m pog. 1. 'slanina'; 2. ekspr. 'podkožno maščobno tkivo pri človeku'; 3. ekspr. 'debela (umazana) knjiga, veliko (umazanih) popisanih listov' < stvn. bav. spëch, srvn. spëc, -ckes, nvn. Speck (ST: 223; ESSJ IV: 97-98; SES: 736).

Označen frazeološki pomen v SSKJ: • pog., ekspr. knjiga se je v nekaj dneh spremenila $v$ špeh 'je postala zelo umazana, zamaščena'.

Neoznačen frazeološki pomen v SSKJ: začel je nabirati špeh 'začel se je rediti'.

F+: nabirati se komu špeh (3 pojavitve); zgled: Špeh se nam nabira, ker noben nas ne trenira in $v$ šoli se ne koncentriram, ker nič ne treniram.

F+: biti kaj (obsežen) špeh (78 pojavitev); zgled: Ko sem pred leti prevajala francosko kuharico, 700 strani obsežen špeh, sem najprej preštudirala Kuharstvo za kuharje.

(1/2) ̌́píca² -e ž 1. pog. 'zelo zožen, priostren končni del česa; konica'; 2. publ. ‘čas, ko se kaj pojavlja v najvišji meri, stopnji; konica' < nvn. Spitze (ST: 224; ESSJ IV: 99; SES: 737). Označen frazeološki pomen v SSKJ: • pog., ekspr. ta človek žene vse na špico 'vse obravnava s prepirom'; pog., ekspr. spor gre na špico 'postaja vedno hujši, se zaostruje' Neoznačen frazeološki pomen v SSKJ: promet ob špicah je zelo gost / prometne špice.

$\mathrm{F}+$ : prometna špica (6 pojavitev); zgled: V prometnih špicah so vsi semaforji ugasnjeni, promet urejajo hupe, hripavi glasovi in nazorni gibi.

$\mathrm{F}+$ : gnati vse na špico (0 pojavitev).

$\mathrm{F}+$ : iti na špico (0 pojavitev).

(1) ̌pôgati -am dov. in nedov., nižje pog. 'dati, žrtvovati' < srvn. spulgen (ST: 225; ESSJ IV: 101; SES: 738).

Označen frazeološki pomen v SSKJ: • nižje pog. špogala si je ostro pripombo 'drznila si jo je izreči'.

F+: špogati si (ostro) pripombo (0 pojavitev).

(1) špráha -e ž nižje pog. 'jezik (sistem za sporazumevanje)' < srvn. sprache, nvn. Sprache (ST: 225).

Označen frazeološki pomen v SSKJ: • zastar. to ni slovenščina, to je kranjska špraha 'slovenski jezik s popačenimi nemškimi besedami’.

F+: kranjska špraha (4 pojavitve); zgled: Kranjsko špraho so uporabljali samo za sporazumevanje s služinčadjo ... 
(1) ̌tála -e ž nižje pog. 'hlev' < srvn. stall, -lles, stvn. stal, nvn. Stall (ST: 227; ESSJ IV: 105; SES: 739).

Označen frazeološki pomen v SSKJ: • nižje pog. njegova soba je prava štala 'je zelo umazana, zanemarjena'.

Označen frazeološki pomen v SSKJ pri iztočnici štálica: • najprej štalica, potem kravica 'najprej je treba imeti stanovanje, materialno osnovo, potem se šele poročiti'.

F+: prava štala (9 pojavitev); zgled: Pri nas je pa prava štala. Pojavljata se še varianti: totalna štala (14 pojavitev), cela štala (14 pojavitev); zgled: Šola je totalna štala. - ... kot vidte, je $v$ hiši cela štala ... in tako naprej in naprej.

$\mathrm{F}+$ : najprej štalca/štalica, potem pa kravca/kravica (83 pojavitev); zgled: Kljub temu bi opozoril, da reka najprej štalca, potem pa kravca ni treba slepo spoštovati ...

(1) ̌tánga -e ž nižje pog. ‘železna palica, drog' < srvn. stange, nvn. Stange (ST: 227; ESSJ IV: 106; SES: 739).

Označen frazeološki pomen v SSKJ: • pog. držati komu štango 'ščititi ga, podpirati ga pri njegovem navadno negativnem delovanju, ravnanju'; star. kupiti štango tobaka 'paličico zvitega tobaka za žvečenje'.

F+: držati komu štango (96 pojavitev); zgled: Generalni direktor drăi štango programskemu direktorju (Janezu Lombergarju) v vsem.

$\mathrm{F}+$ : štanga tobaka (0 pojavitev).

(1) štànt $m$ 1. nižje pog. 'stojnica'; 2. nar. 'del kozolca med dvema stebroma; okno' < srvn. stant, nvn. Stand, srvn. bestant (ST: 227-228; SES: 739).

Označen frazeološki pomen v SSKJ: • star. dati, vzeti kmetijo v štant 'v najem'; star. biti v štantu 'pri kom stanovati v tuji, najeti hiši'.

$\mathrm{F}+$ : dati, vzeti $\boldsymbol{v}$ štant (3 pojavitve); zgled: ... in tega bo tudi prodal in si kupil spet novega pa bo vzel $\boldsymbol{v}$ štant tuj grunt, se en čas $z$ denarji še bahal ...

$\mathrm{F}+$ : biti/̌̌iveti/stanovati $\boldsymbol{v}$ štantu (3 pojavitve); zgled: ... Kot najemniki, mi rečemo v štantu smo živeli, v hišici pri hosti v Biški vasi.

(2/3) ̌tíma -e ž nižje pog. 'glas' < srvn. stimme, nvn. Stimme (ST: 230; ESSJ IV: 113; SES: 741).

Neoznačen frazeološki pomen v SSKJ: ta pa ima štimo 'glasno govori; lepo poje'. Manjkajoči frazeološki pomen v SSKJ: živeti od božje štime 'nič jesti in piti'.

F+: imeti štimo (1 pojavitev); zgled: Ja, dober glas je zelo pomemben. Poznamo poklice, pri katerih resnično ni vseeno, kakšno štimo ima $k d o$.

F+: živeti od boz̆je štime (3 pojavitve); zgled: Ali naši ljubi gospodje mislijo, da bomo živeli in dajali od »božje štime»?

(1) Štréna -e ž pog. 'preja, zvita v več enako dolgih navojev' < srvn. strëne, strën, nvn. Strähne (ST: 231; ESSJ IV: 120; SES: 742).

Označen frazeološki pomen v SSKJ: • pog. meša $\boldsymbol{m u}$ štrene 'preprečuje, ovira njegove načrte'; pog. zlepa mu ne zmanjka štrene 'snovi za pogovor, pripovedovanje'.

F+: mešati komu štrene (706 pojavitev); zgled: ... drugi politiki mešajo štrene drug drugemu in si pred volitvami mečejo polena v glavo. Varianta: zmešati štrene (226 pojavitev); zgled: Štrene jim bodo poskušali zmešati najboljši slovenski mladinci, ki si tokrat gotovo obetajo več kot le nabiranje izkušenj ...

$\mathrm{F}+$ : zmanjkati komu štrene (33 pojavitev); zgled: Če pa vam štrene vendarle zmanjka, potem užalite pokrovitelja ali gostitelja, to bo zagotovo izvabilo aplavz! 
(1) ̌̌tríhati -am nedov., nižje pog. 'barvati, pleskati' < srvn. strîche, strîchen, stvn. strîhhan, nvn. streichen (ST: 231-232; SES: 743).

Označen frazeološki pomen v SSKJ: • pog. gliha vkup štriha 'ljudje podobnih, navadno slabih lastnosti se radi družijo, dobro razumejo'.

F+: gliha vkup štriha (36 pojavitev); zgled: Kar pa se morale tiče, gliha vkup štriha, pravi star slovenski pregovor.

(1) Štrìk štríka m nižje pog. 'vrv' < srvn. stric, strick, nvn. Strick (ST: 232; ESSJ IV: 121; SES: 743).

Označen frazeološki pomen v SSKJ: • nižje pog. najraje bi si dal štrik za vrat 'se obesil'; pog. kamor je šel bik, naj gre še štrik 'če sem izgubil, zapravil veliko, lahko še to malenkost'. F+: dati si štrik za vrat (3 pojavitve); zgled: Zdaj bi morala zadevo le še dokončno urediti, se pravi premoženje prepisati, sebi pa dati »štrik za vrat». Pojavita se še varianti natakniti si štrik okoli vratu (1 pojavitev), zavezati si štrik okoli vratu (1 pojavitev); zgled: Marsikdo govori v prepričanju, da ga bodo potem spustili, in marsikdo si tako natakne »štrik« okoli vratu. - Lahko se le zjoče od obupa in si zaveže kakšen štrik okrog vratu, kajti v hladno in nedostopno telo presojevalčeve duše ne bo prodrl ali ga otoplil.

F+: kamor je šel bik, naj gre še štrik (60 pojavitev); zgled: Kamor je šel bik, naj gre še štrik, saj se samo enkrat živi, sva se tolažila ...

(1) távžent -a m nav. mn., nižje pog. 'z rodilnikom nedoločena večja količina; tisoč' < srvn. bav. *taužent, srvn. tûsent, nvn. tausend (ST: 237; SES: 752).

Označen frazeološki pomen v SSKJ: • nižje pog. dekle ima tavžente 'je bogato'.

$\mathrm{F}+$ : imeti tavžente (0 pojavitev).

(1) trón -a m nižje pog. 'prestol' < nvn. Tron, srvn. trôn, thrôn (ST: 240; SES: 786).

Označen frazeološki pomen v SSKJ: • star. stopiti pred božji tron 'umreti'.

$\mathrm{F}+$ : stopiti pred božji tron (0 pojavitev). Varianta: odpeljati pred božji tron (1 pojavitev); zgled: ... kar pa se je zgodilo čez sedem let, so ponj prišli angeli in ga odpeljali pred boŭji tron.

(2) túšs ${ }^{2}$-a m pog. 'prha' < bav. avstr. Dusche (ST: 242; ESSJ IV: 250; SES: 793).

Neoznačen frazeološki pomen v SSKJ: novica je nanjo delovala kot mrzel tuš / srečanje je bilo hud tuš zanj 'hudo razočaranje, neprijetno presenečenje'.

F+: mrzel tuš (104 pojavitve); zgled: Mrzel tuš nam pripravi obvestilo, nalepljeno na notranji strani vetrobranskega stekla. Varianta: hladen tuš (519 pojavitev); zgled: Prihod v Slovenijo je bil za najina otroka hladen tuš, saj nista razumela niti besedice slovensko.

F+: hud tuš (1 pojavitev); zgled: Našli so nekega drugega reveža. Ha! To je moral biti hladen tuš za preklemanega Morsa. Hud tuš, če je vodo odprl Strange.

(1/3) vága -e ž 1. pog. 'tehtnica'; 2. pog. 'teža' < stvn. wâga, srvn. wâge, nvn. Waage (ST: 243; ESSJ IV: 274; SES: 804).

Označen frazeološki pomen v SSKJ: • pog. za vse člane kolektiva naj bo ista mera in vaga 'vsi se naj ocenjujejo z enakimi merili; vsi naj bodo enakopravni'; pog. kupovati, prodajati na vago 'kupovati, prodajati tako, da se blago sproti natehta'; pog. njegov položaj je na vagi 'je negotov'; preg. (dobra) mera in vaga v nebesa pomaga 'pri tehtanju, merjenju blaga je potrebna pravičnost'.

Manjkajoči frazeološki pomen v SSKJ: dati kaj na vago 'pretehtati kaj'.

$\mathrm{F}+$ : ista mera in vaga (0 pojavitev). 
$\mathrm{F}+$ : kupovati, prodajati na vago (10 pojavitev); zgled: Vole so prodajali na vago, zato so jih začeli krmiti zgodaj zjutraj, da so bili čim težji.

F+: biti kaj na vagi (7 pojavitev); zgled: Ampak moj ugled je na vagi! Moj! Ko bi mu vsaj verjel, Hanžku!

$\mathrm{F}+$ : (dobra) mera in vaga v nebesa pomaga (3 pojavitve); zgled: Včasih so rekli: Prava mera in vaga v nebesa pomaga.

$\mathrm{F}+$ : dati/položiti kaj na vago (3 pojavitve); zgled: V takem primeru bi bilo treba dati na vago moje informacije in informacije nekoga drugega. - ... dobivamo nove in nove argumente, $k i$ jih polagamo na vago.

(1) vínar -ja m 1. nekdaj 'avstrijski novec za pol krajcarja'; 2. ekspr. 'kovanec majhne vrednosti' < bav. avstr. Wiener-(pfennig, geld) (ST: 246; ESSJ IV: 318; SES: 821).

Označen frazeološki pomen v SSKJ: • star. ne bo te stalo niti vinarja 'popolnoma nič'; star. plačati vse do zadnjega vinarja 'popolnoma vse'; star. gledati na vsak vinar 'biti varčen; biti skop'; preg. en krivičen vinar deset pravičnih sne 'zaradi krivično pridobljenega denarja, premoženja še veliko pravično pridobljenega ne prinaša sreče, koristi'.

$\mathrm{F}+$ : ne imeti/dati niti vinarja (2 pojavitvi); zgled: Segla sta v žep, toda nobeden ni imel pri sebi niti vinarja. - ... revije, časnike itd. ... ker ji niti vinarja nista dali ne krovna monopolistična gospodarsko-kulturna baza ...

$\mathrm{F}+$ : plačati vse do zadnjega vinarja (0 pojavitev). Varianta: vzeti/odšteti zadnji vinar (2 pojavitvi); zgled: Vsakemu, najsi je bil papist, najsi je bil protestant, smo vzeli zadnji vinar. $\mathrm{F}+$ : gledati na vsak vinar (0 pojavitev).

$\mathrm{F}+$ : en krivičen vinar deset pravičnih sne (0 pojavitev).

(1) víncar -ja m zastar. 'vinogradnik'< srvn. winzer, nvn. Winzer (ST: 246; ESSJ IV: 318). Označen frazeološki pomen v SSKJ: • zastar. rožnik deževen - vincar reven 'če je junij deževen, vinogradnik nima dobre letine'.

$\mathrm{F}+$ : rožnik deževen - vincar reven (0 pojavitev). Najdemo pa varianti rožnik deževen - viničar reven (11 pojavitev), rožnik deževen - vinogradnik reven (6 pojavitev); zgled: Tako pravi tudi naslednji pregovor: »Rožnik deževen, viničar reven.»-Rožnik - junij: Rožnik deževen, vinogradnik reven.

(1) víža -e ž 1. star. 'napev'; 2. pog. 'krajša, navadno narodno-zabavna skladba'; 3. star., v prislovni rabi, v zvezi z 'na način' < srvn. wîse, stvn. wîsa, nvn. Weise (ST: 246; ESSJ IV: 327-328; SES: 825-826).

Označen frazeološki pomen v SSKJ: • pog., ekspr. na (vse) mile viže mu je prigovarjal 'zelo, na vse načine'; star. na vsako vižo bo prišel 'gotovo'.

$\mathrm{F}+$ : na vse mile viže (44 pojavitev); zgled: V preteklosti smo jim želeli na vse mile viže dopovedati, kaj je to Slovenija ...

$\mathrm{F}+$ : na vsako vižo (2 pojavitvi); zgled: Jaz bi svetovala na vsako vižo iti u Beč ...

(2) zós -a m 1. nižje pog. 'omaka' < nvn. Soße 'omaka' tudi 'neprijetna stvar, neprijeten položaj (ST: /; ESSJ IV: 425; SES: /).

Neoznačen frazeološki pomen: 2. nizko 'neprijeten, zapleten položaj': potegniti koga iz zosa; zaiti v velik zos. K, 120: biti (znajti se) v zosu; potunkati/spraviti koga v zos, pasti v zos. $\mathrm{F}+$ : biti v (istem/krepkem/velikem/podobnem ...) zosu (38 pojavitev): Pa sem bil v zosu. $\mathrm{F}+$ : pasti v zos (2 pojavitvi): ... sem se diskretno odstranil, a s tem padel v še večji zos.

$\mathrm{F}+$ : znajti se v zosu (4 pojavitve): ... beganju iz ene pivnice $v$ drugo sem se nenadoma znašel $\boldsymbol{v}$ zosu. Posamezne pojavitve so tudi za glagole čofniti, pristati, utapljati se, zgrmeti, obsedeti, zabresti $v$ zos $(u)$. 
(1/3) Žákelj -klja m pog. 'vreča' < bav. avstr. Säcklein, nar. sack•l, srvn. seckel (ST: 248; ESSJ IV: 434; SES: 863).

Označen frazeološki pomen v SSKJ: • pog., evfem. držati žakelj 'biti soudeležen pri kraji, ropu'; zastar. dati hišo v žakelj 'ometati jo'; pog. dati koga v žakelj 'premagati koga, biti boljši od koga'; pog. ženska, oblečena v žakelj 'v vrečasto krojeno obleko'; pog. jemati iz skupnega žaklja 'iz skupne blagajne, skupnega sklada'; pog. ko je bil žakelj prazen, sta šla narazen 'ko ni bilo več zaloge, imetja'; ekspr. kupiti, vzeti mačka v žaklju 'kupiti, dobiti kaj, ne da bi stvar prej poznal, videl'; pog. prazen žakelj ne stoji pokonci 'brez zadostne hrane človek ni sposoben za delo, se ne počuti dobro'.

Manjkajoči frazeološki pomen v SSKJ: soditi/spadati v isti žakelj ‘biti enak'; žakelj brez dna 'nikoli ni dovolj, opravilo, ki ni nikoli končano'.

F+: drăati žakelj (14 pojavitev); zgled: Saj je tisti, ki žakelj drŭi, ravno toliko kriv kot tisti, ki $v$ žakelj daje.

$\mathrm{F}+$ : dati hišo $v$ žakelj (0 pojavitev).

$\mathrm{F}+$ : dati koga v žakelj (2 pojavitvi); zgled: In tudi Berchtesgaden je bil s tremi milijoni prekratek, v̌akelj ga je dal Albertville s sedmimi ...

$\mathrm{F}+$ : biti oblečen $v$ žakelj ( 0 pojavitev).

F+: jemati iz skupnega žaklja (16 pojavitev); zgled: Veliko lažje je jemati iz skupnega žaklja brez jasno opredeljenega prejemnika, kot pa s čistimi računi in dobrimi prijatelji, kot to velja, skleniti dogovor ... Varianta: jemati iz istega žaklja (9 pojavitev); zgled: Ker je šel denar iz istega žaklja, je postojnska regija 1987 spraševala ...

$\mathrm{F}+$ : ko je bil žakelj prazen, sta šla narazen (0 pojavitev).

F+: kupiti mačka v žaklju (82 pojavitev; K, 63-64, 122); kupovati mačka v žaklju (70 pojavitev); dobiti mačka v žaklju (12 pojavitev); vzeti mačka v žaklju (2 pojavitvi); prodati mačka v žaklju (14 pojavitev; K: 64); najeti mačka v žaklju (1 pojavitev); zgled: ... če kupujemo po pošti iz oddaljenih krajev, se moramo ves čas zavedati, da utegnemo kupiti mačka $\boldsymbol{v}$ žaklju. - ... ki je za nov avto odštel veliko denarja, dobil pa mačka v žaklju. - Če nekaj kupuješ, nočeš vzeti mačka v žaklju. - Pri nakupu zemljišča ali stanovanja je treba paziti, da nepremičninarji ne prodajo mačka v žaklju. - Potem ko lastniki ugotovijo, da so najeli mačka v žaklju ...

$\mathrm{F}+$ : prazen žakelj ne stoji pokonci (23 pojavitev); zgled: Vsi vemo, da prazen žakelj ne stoji pokonci, kaj šele da bi ustvarjalno razmišljal.

F+: (soditi/spadati) v isti žakelj (19 pojavitev); zgled: Nikakor ne bi smeli vseh zmetati v isti žakelj.

F+: (biti) žakelj brez dna (11 pojavitev); zgled: Lahko mirno rečemo, da je državna blagajna žakelj brez dna.

(1/2) žégen -gna m 1. pog. 'blagoslov' < stvn. sëgan, srvn. sëgen, stvn. seganōn, srvn. sëgenen, nvn. Segen, segnen (ST: 250; ESSJ IV: 441; SES: 865).

Označen frazeološki pomen v SSKJ: • pog. poročila sta se brez žegna 'civilno'.

Neoznačen frazeološki pomen v SSKJ: dobiti žegen za uvoz surovin 'soglasje'; 6. pog., ekspr., v zvezi blažev žegen 'kar je neučinkovito'.

$\mathrm{F}+$ : poročiti se brez žegna (0 pojavitev).

$\mathrm{F}+$ : dati žegen (40 pojavitev); dobiti žegen (39 pojavitev); zgled: Če torej župan ne bo pri volji, da bi dal žegen za samoprispevek, tega ne morejo razpisati ... - Predlog je podprlo kulturno ministrstvo, dobil pa je tudi žegen varuhov konkurence.

F+: blažev žegen (117 pojavitev; K, 27-28); zgled: Zdravniki pogosto predpišejo kakšen »blažev žegen « in bolnik ozdravi ... 
- (1) Žláhta -e ž 1. pog. 'sorodstvo, sorodniki'; 2. zastar. 'plemstvo' < stvn. slahta, srvn. 퍼 $\quad$ slahte, slaht (ST: 252; ESSJ IV: 461; SES: 871).

Označen frazeološki pomen v SSKJ: • pog. fant je naša žlahta 'naš sorodnik'; pog. najbrž me ne poznaš, čeprav sva žlahta 'sorodnika'; star. nisem vedel, da je moja žlahta 'moj sorodnik'; pog. midva sva si še nekaj v žlahti 'dolguješ mi še nekaj’; pog. biti (si) vžlahti (s kom) 'v sorodstvu, sorodu',' žlahta je strgana plahta 'od sorodstva človek ne more pričakovati pomoči, koristi'; dober sosed je več vreden kot vsa z̆lahta 'od soseda lahko človek dobi več pomoči, ima več koristi kot od sorodnikov'.

F+: žlahta je strgana plahta (12 pojavitev); zgled: Tudi politična žlahta je včasih strgana plahta. Varianta: žlahta je raztrgana plahta (10 pojavitev); zgled: ... nam grejo na živce samo zato, ker je žlahta raztrgana plahta in ker jih tako dobro poznamo.

$\mathrm{F}+$ : (dober) sosed je več vreden kot vsa žlahta (3 pojavitve); zgled: Rek, da je najbližji sosed več vreden kot včasih cela žlahta, še danes drži ... Varianta: (dober) sosed je boljši kot vsa žlahta (6 pojavitev); zgled: Saj veste, kako pravi slovenski pregovor dober sosed je boljši kot vsa žlahta.

(1) žlàk žláka m 1. zastar. 'poškodba, rana (od udarca)' < srvn. slac, -ges, stvn. slag, nvn. Schlag (ST: 252; ESSJ IV: 462; SES: 871).

Označen frazeološki pomen v SSKJ: • star. božji žlak ga je zadel '(možganska) kap'; star. napiti se, spreti se na (vse) boŭje, mile, mrtve žlake 'zelo'.

F+: boz̆ji žlak je zadel koga (3 pojavitve); zgled: Človeka bi zadel božji žlak, ko čuje ali prebere povzetek škofovske konference o socialnih vprašanjih in o njihovih pobudah. Varianta: božji žlak je udaril koga (1 pojavitev); zgled: Če me, na priliko, udari božji žlak, bom nekje obležal in vse načrte bo zagrnila črna noč.

$\mathrm{F}+$ : na (vse) božje žlake (0 pojavitev).

$\mathrm{F}+$ : na (vse) mile žlake (1 pojavitev); zgled: ... kuhajo svojo župo, stradalne kure, na mile žlake, ilustrativen ...

F+: na (vse) mrtve žlake (1 pojavitev); zgled: ... se na mrtve žlake žene na cesti pred skupščino maroderska, v občasnih časopisnih oznanilih pa rezervna razumniška pehota iste stranke ...

(1) žnóra -e ž nižje pog. 'vrvica' < stvn., srvn. snuor, nvn. Schnur (ST: 254; ESSJ IV: 474; SES: 873).

Označen frazeološki pomen v SSKJ: • nižje pog. vse gre kakor po žnori 'vse gre kakor po maslu'. ${ }^{3}$

F+: vse gre kakor/kot po žnori (1 pojavitev); zgled: Na jubilejni, 40. Zlati lisici na Pohorju, se je skoraj vse odvijalo kot po »žnori" ...

(1) žóld -a m zastar. 'vojaška služba' < srvn. solt, -des (ST: 255; ESSJ IV: 476).

Označen frazeološki pomen v SSKJ: • star. dobivati majhen žold 'plačilo, plačo'.

$\mathrm{F}+$. dobivati majhen žold ( 0 pojavitev).

(1/3) ̌úpa ${ }^{2}$-e ž 1 . nižje pog. 'juha' < poznosrvn., zgodnjenvn. Suppe k srvn. supen, nvn. Suppe (ST: 255; ESSJ IV: 485; SES: 875).

Označen frazeološki pomen v SSKJ: • ekspr. ta pa ni po (prežgani) župi priplaval 'je bister, prebrisan'.

2 V frazeološkem gnezdu so zapisane tudi besedne zveze, ki niso frazeološke, npr. naša žlahta, biti v žlahti, saj je pomen teh zvez predvidljiv iz pomena posameznih sestavin, torej ne gre za frazeološki pomen.

3 SSKJ frazem razlaga z drugim frazemom; gre za pomen 'vse poteka brez zapletov, uspešno'. 
Manjkajoči frazeološki pomen v SSKJ s sestavino župa (čeprav najdemo pa zgleda s knjižno varianto juha: • pog., ekspr. ta pa ni po (prežgani) juhi priplaval ‘je bister, prebrisan'; preg. nobena juha se ne poje tako vroča, kot se skuha 'vsaka zahteva, vsak ukrep je v začetku videti hujši, kot pa se izkaže kasneje'): nobena župa se ne poje tako vroča, kot se skuha 'vsak ukrep, zahteva je na začetku videti hujši, kot se izkaže kasneje'; kakršno župo si boš skuhal, takšno boš pojedel 'sam boš trpel posledice svojih nepremišljenih dejanj'.

$\mathrm{F}+$ : priplavati po (prežgani/kisli/slani) župi (51 pojavitev); zgled: Tako mu vsaj ne bodo več očitali, da je v gospodarstvo priplaval po župi.

$\mathrm{F}+$ : nobena župa se ne poje tako vroča, kot se skuha (4 pojavitve); zgled: Ker verjamem v ljudsko modrost, da se nobena juha ("župa») ne poje tako vroča, kot se skuha, sem prepričan, da bodo morali godljo ...

F+: kakršno župo si boš skuhal, takšno boš pojedel (1 pojavitev); zgled: Sam želim, da ostanemo vsi skupaj, toda zdaj je, kar je: kakršno župo si bodo skuhali, takšno bodo pač morali pojesti.

$\mathrm{F}+$ : zakuhati komu (lepo) župo ${ }^{4}$ (1 pojavitev); zgled: ... seveda, če je on zakuhal to župo, da so dela ustavljena ... Zelo verjetno gre $\mathrm{v}$ tem primeru za sestavinsko varianto $\mathrm{k}$ frazemu skuhati/zakuhati komu (lepo) kašo.

\section{Zaznamovanost frazemskih sestavin}

3.1 Iz spodnje preglednice lahko razberemo, da so germanizmi od R do Ž, ki so sestavine frazemov, v SSKJ največkrat označeni s stilno-plastnimi kvalifikatorji (76,20 \%), med njimi pa sta najpogostejša kvalifikatorja nižje pogovorno $(71,87 \%)$ in pogovorno $(25,00 \%)$. Delež časovno-frekvenčnih kvalifikatorjev je manjši $(23,80 \%)$.

Preglednica 1: Kvalifikatorske oznake germanizmov od R do Ž v SSKJ

\begin{tabular}{|l|l|l|l|l|l|l|}
\hline \multirow{2}{*}{ Kvalifikator } & \multicolumn{3}{|c|}{ Stilno-plastni } & \multicolumn{2}{c|}{ Časovno-frekvenčni } & Ekspresivni \\
\hline & nižje pog. & pog. & nar. & & nekdaj & ekspr. \\
\hline rajda & + & & & & & \\
\hline rajža & & & & star. & & \\
\hline regiment & & & & star. & & \\
\hline rihta $^{1}$ & & & & star. & & \\
\hline rihta $^{2}$ & + & & & & & \\
\hline rom ++ & & & & & \\
\hline šlager & & & & zastar. & & \\
\hline šlapa & + & & & & & \\
\hline šnofati & + & & & & & \\
\hline šparati & + & & & & & \\
\hline špas & + & & & & & \\
\hline špeh & & + & & & & \\
\hline špica & & + & & & & \\
\hline
\end{tabular}

${ }_{4}$ Pogostejša je sestavinska zapolnitev s kašo. 


\begin{tabular}{|c|c|c|c|c|c|c|}
\hline \multirow[t]{2}{*}{ Kvalifikator } & \multicolumn{3}{|c|}{ Stilno-plastni } & \multicolumn{2}{|c|}{ Časovno-frekvenčni } & \multirow{2}{*}{$\begin{array}{c}\text { Ekspresivni } \\
\text { ekspr. }\end{array}$} \\
\hline & nižje pog. & pog. & nar. & & nekdaj & \\
\hline špogati & + & & & & & \\
\hline špraha & + & & & & & \\
\hline štala & + & & & & & \\
\hline štanga & + & & & & & \\
\hline štant & + & & & & & \\
\hline šterna & + & & & & & \\
\hline štima & + & & & & & \\
\hline štrena & & + & & & & \\
\hline štrihati & + & & & & & \\
\hline štrik & + & & & & & \\
\hline tavžent & + & & & & & \\
\hline tron & + & & & & & \\
\hline tuš $\check{s}^{2}$ & & + & & & & \\
\hline vaga & & + & & & & \\
\hline vinar & & & & & + & \\
\hline vincar & & & & zastar. & & \\
\hline viža & & & & star. & & \\
\hline zos & + & & & & & \\
\hline žakelj & & + & & & & \\
\hline žegen & & + & & & & \\
\hline žlahta & & + & & & & \\
\hline žlak & & & & zastar. & & \\
\hline žnora & + & & & & & \\
\hline žold & & & & zastar. & & \\
\hline župa $^{2}$ & + & & & & & \\
\hline
\end{tabular}

\section{Korelacija med zaznamovanostjo sestavine in zaznamovanostjo frazema}

4.1 V SSKJ se zaznamovanost frazemske sestavine ujema z zaznamovanostjo frazema:

star. rajža - star. nobena rajža; star. regiment - star. sedemnajsti regiment $v$ stari Avstriji; nižje pog. šnofati - nižje pog. šnofati tobak; nižje pog. šparati - nižje pog. šparati se pri delu; nižje pog. špas - nižje pog. ne biti za špase; pog. špica ${ }^{2}$ - pog., ekspr. gnati vse na špico; pog. špica ${ }^{2}$ - pog., ekspr. iti na špico; nižje pog. špogati - nižje pog. špogati si (ostro) pripombo; nižje pog. štala - nižje pog. prava štala; pog. štrena - pog. mešati komu štrene; pog. štrena - pog. zmanjkati komu štrene; nižje pog. štrik - nižje pog. dati si štrik za vrat; nižje pog. tavžent - nižje pog. imeti tavžente; pog. vaga - pog. biti ista mera in vaga; pog. vaga - pog. kupovati, prodajati na vago; pog. vaga - pog. biti kaj na vagi; nekdaj vinar - star. ne stati/ imeti/dati niti vinarja; nekdaj vinar - star. plačati vse do zadnjega vinarja; nekdaj 
vinar - star. gledati na vsak vinar; zastar. vincar - zastar. rožnik deževen - vincar reven; star. viža - star. na vsako vižo; pog. žakelj - pog., evfem. držati žakelj; pog. žakelj - pog. dati koga v žakelj; pog. žakelj - pog. biti oblečen v žakelj; pog. žakelj - pog. jemati iz skupnega žaklja; pog. žakelj - pog. ko je bil žakelj prazen, sta šla narazen; pog. žakelj - pog. prazen žakelj ne stoji pokonci; pog. žegen - pog. poročiti se brez žegna; zastar. žlak - star. zadeti koga božji žlak; zastar. žlak - star. na (vse) božje, mile, mrtve žlake; nižje pog. žnora - nižje pog. vse gre kakor po žnori; zastar. žold - star. dobivati majhen žold.

4.2 Primerjava kvalifikatorskih oznak frazemskih sestavin in frazemov je pokazala, da se zaznamovanost sestavine ujema z zaznamovanostjo frazema v 55,55 \%, kar pomeni, da določena povezava vendarle obstaja.

V primerih, ko se zaznamovanost frazemske sestavine ne ujema z zaznamovanostjo frazema, je mogoče opaziti, da ima frazem navadno višjo vrednost oziroma stopnjo, je torej manj zaznamovan od germanizma.

Premike v oznakah je mogoče zaznati:

a) med nižje pogovorno in pogovorno zaznamovanostjo $(28,57 \%)$; npr. nižje pog. rihta ${ }^{2}$ - pog., ekspr. (biti) pokrita rihta; nižje pog. rom - pog. (biti) za v rom; nižje pog. špas - pog., ekspr. biti špas; nižje pog. špas - pog., ekspr. (biti) drag špas; nižje pog. špas - pog., ekspr. (biti) velik špas; nižje pog. štanga - pog. držati komu štango; nižje pog. štrihati - pog. gliha vkup štriha; nižje pog. štrik - pog. kamor je šel bik, naj gre še štrik.

b) med nižje pogovorno in ekpresivno zaznamovanostjo (21,43\%); npr. nižje pog. rajda - ekspr. cela rajda; nižje pog. rihta $^{2}$ - pog., ekspr. (biti) pokrita rihta; nižje pog. špas - pog., ekspr. biti kaj drag/velik špas; nižje pog. zos - nizko biti v zosu; nižje pog. župa ${ }^{2}$ - ekspr. ne priplavati po prežgani župi.

c) med nižje pogovorno in časovno-frekvenčno zaznamovanostjo (17,86 \%); npr. nižje pog. špraha - zastar. kranjska špraha; nižje pog. štanga - star. štanga tobaka; nižje pog. štant - star. dati, vzeti v štant; nižje pog. štant - star. biti v štantu; nižje pog. tron - star. stopiti pred božji tron.

c) med nižje pogovorno/pogovorno zaznamovanostjo in pregovorom brez označevalnika (14,29 \%); npr. nižje pog. šparati - kdor jezika špara, kruha strada; pog. vaga - preg. (dobra) mera in vaga v nebesa pomaga; pog. žlahta - žlahta je strgana plahta; pog. žlahta - dober sosed je vreden več kot vsa žlahta.

\section{Slovarska zajetost in živost frazemov}

5.1 Frazemi, ki so bili v SSKJ razvrščeni v frazeološko gnezdo in so v korpusu FidaPLUS potrjeni (44,44 \%), so: cela rajda, (biti) pokrita rihta, šlager leta/sezonel stoletja, kdor jezika/besede špara, kruha strada, (biti) drag špas, (biti) velik špas, prava/totalna/cela štala, držati komu štango, dati/vzeti v štant, biti/živeti/stanovati v štantu, mešati/zmešati komu štrene, zmanjkati komu štrene, gliha vkup štriha, dati/natakniti/zavezati si štrik za/okoli vrat(u), kamor je šel bik, naj gre še štrik, kupovati/prodajati na vago, biti kaj na vagi, (dobra) mera in vaga v nebesa pomaga, 
stati/imeti/dati niti vinarja, plačati/vzeti/odšteti zadnji vinar, rožnik deževen - vincar/viničar/vinogradnik reven, na (vse) mile viže, na vsako vižo, držati žakelj, dati koga vžakelj, jemati iz skupnega/istega žaklja, kupiti/kupovati/dobiti/vzeti/prodati/ najeti mačka $v$ žaklju, prazen žakelj ne stoji pokonci, žlahta je strgana/raztrgana plahta, (dober) sosed je več vreden/boljši kot vsa žlahta, zadeti/udariti koga božji žlak, na (vse) mile, mrtve žlake, vse gre kakor/kot po žnori, priplavati po (prežgani, kisli, slani) župi.

5.2 Frazemi, ki so v SSKJ razvrščeni v frazeološko gnezdo, in v korpusu FidaPLUS nepotrjeni (29,63 \%): nobena rajža, sedemnajsti regiment v stari Avstriji, (biti) za v rom, časopisni šlager, šnofati tobak, šparati se pri delu, biti špas, ne biti za špase, gnati vse na špico, iti na špico, špogati si (ostro) pripombo, štanga tobaka, imeti tavžente, stopiti pred božji tron, biti ista mera in vaga, gledati na vsak vinar, en krivičen vinar deset pravičnih sne, dati hišo v žakelj, biti oblečen v žakelj, ko je bil žakelj prazen, sta šla narazen, poročiti se brez žegna, dobivati majhen žold.

5.3 Frazemi, ki v SSKJ niso zabeleženi v ustreznem gnezdu, in v korpusu FidaPLUS so potrjeni (13,58 \%): cel regiment, krvava rihta, biti šlapa, nabirati špeh, prometna špica, imeti štimo, mrzel/hladen/hud tuš, biti v zosu, dati/dobiti žegen, blažev žegen.

5.4 Frazemi, ki v SSKJ niso zabeleženi, v korpusu FidaPLUS pa potrjeni (12,35 \%): iti na rajžo, biti kaj špeh, najprej štalca/štalica, potem pa kravca/kravica, živeti od božje štime, dati/položiti kaj na vago, soditi/spadati v isti žakelj, žakelj brez dna, zakuhati komu (lepo) župo, nobena župa se ne poje tako vroča, kot se skuha, kakršno župo si boš skuhal, takšno boš pojedel.

5.5 Iz pregleda je razvidno, da je približno $87,65 \%$ obravnavanih frazemov tako ali drugače zajetih v SSKJ. Med njimi je 44,44 \% frazemov zajetih v frazeološkem gnezdu SSKJ in 13,58 \% v ponazarjalnem gradivu SSKJ tudi korpusno potrjenih in v rabi živih. Le $12,35 \%$ je takih frazemov, ki jih v SSKJ ni, a imajo potrditev $\mathrm{v}$ korpusu. $\mathrm{S}$ stališča zbranega frazeološkega gradiva $\mathrm{z}$ germanizmi kot sestavino lahko ugotovimo, da SSKJ v 58,20 \% odraža živo in še danes aktualno rabo ter da je delež živega, a manjkajočega precej nizek (12,35\%).

SSKJ pri opredelitvi, kaj je frazeološko in kaj ne, kaže sicer že znano omahovanje (Majdič 2004: 68). Kot je že bilo opozorjeno, v frazeoloških gnezdih najdemo marsikaj, kar tja ne spada, npr. besedne zveze, ki niso frazeološke (rihtati koga, rihtati otroka za $v$ šolo, rihtati stanovanje, šparati koga, knjiga se je spremenila $v$ špeh, naša žlahta ipd.), in stalne nefrazeološke besedne zveze (filmska špica, stalna špica, čakati na štantu, preplezati turen ipd.). Frazeološke zveze najdemo tudi v ponazarjalnem gradivu, kar dokazujejo tudi korpusni podatki, npr. cel regiment, krvava rihta, biti šlapa, nabirati špeh, prometna špica, imeti štimo, mrzel/hladen/ hud tuš, dati/dobiti žegen za kaj, blažev žegen. 


\section{Rezultati vprašalnika in interpretacija}

6.1 Z vprašalnikom smo želeli ugotoviti, kako mlajša generacija (starost 20-23 let) pozna frazeme z germanizmi, v kakšni meri so germanizmi še prisotni v vsakdanjem pogovornem jeziku mladih in katere druge sestavine jih nadomeščajo. Vprašalnik vsebuje 72 frazemov, ki jim je pripisan frazeološki pomen, ker nismo preverjali razumevanja frazemov, ampak le živost in njihovo poznavanje. Odgovarjalo je 54 anketirancev, študentov 2. letnika Filozofske fakultete Maribor, smer Slovenski jezik s književnostjo, v študijskem letu 2008/09. Vprašani so ponujene frazeme označili z znakom +, če frazem uporabljajo; z znakom 0, če frazem redko uporabljajo; z znakom -, če frazema ne poznajo. Nato je bilo treba zapisati še varianto frazema, ki ga morebiti uporabljajo namesto ponujenega.

Preglednica 2: Rezultati vprašalnika

\begin{tabular}{|l|l|l|l|l|}
\hline Frazem & + & 0 & - & Varianta frazema \\
\hline cela rajda & 6 & 17 & 31 & $\begin{array}{l}\text { cel haufen, cela vrsta, cela riža, } \\
\text { cela rajža, cela gruča }\end{array}$ \\
\hline nobeno rajžo & 1 & 6 & 47 & \\
\hline cel regiment & 10 & 28 & 17 & cel kup \\
\hline krvava rihta & 3 & 11 & 40 & \\
\hline (biti) pokrita rihta & 1 & 3 & 50 & (biti) zaprta knjiga \\
\hline (biti) za v rom & 1 & 1 & 52 & \\
\hline časopisni šlager & 2 & 10 & 42 & \\
\hline šlager leta, sezone & 4 & 17 & 33 & hit leta \\
\hline biti šlapa & 11 & 16 & 26 & biti pes, biti cucek, biti copata, \\
& & & & biti capa \\
\hline šnofati tobak & 27 & 16 & 11 & snifati tobak \\
\hline šparati se pri delu & 48 & 5 & 1 & \\
\hline kdor jezika špara, kruha strada & 32 & 14 & 8 & \\
\hline biti kaj špas & 6 & 24 & 24 & biti hec, biti mala malica \\
\hline (biti) drag špas & 33 & 14 & 7 & biti drag hec, biti drag šport \\
\hline (biti) velik špas & 26 & 14 & 14 & biti ful fajn \\
\hline ne biti za špase & 34 & 16 & 4 & ne biti za hece, ne biti za fore \\
\hline nabirati špeh & 36 & 11 & 7 & narazen iti \\
\hline prometna špica & 36 & 13 & 5 & prometna konica, prometna kača \\
\hline gnati vse na špico & 0 & 11 & 43 & \\
\hline iti na špico & 2 & 10 & 42 & iti na nož \\
\hline špogati si (ostro) pripombo & 0 & 5 & 49 & \\
\hline kranjska špraha & 20 & 22 & 12 & kranjski guč \\
\hline prava štala & 47 & 7 & 0 & cela štala \\
\hline najprej štalca, potem pa kravca & 50 & 3 & 1 & \\
\hline držati (komu) štango & 23 & 15 & 16 & dajati komu potuho \\
\hline pripeti k štangi & 7 & 8 & 39 & \\
\hline & & & \\
\hline
\end{tabular}


$>>>$

\begin{tabular}{|c|c|c|c|c|}
\hline Frazem & + & 0 & - & Varianta frazema \\
\hline štanga tobaka & 6 & 6 & 42 & \\
\hline dati, vzeti v štant & 7 & 11 & 36 & \\
\hline biti v štantu & 4 & 12 & 38 & \\
\hline imeti štimo & 40 & 10 & 4 & imeti štimungo, imeti posluh \\
\hline mešati (komu) štrene & 49 & 4 & 1 & \\
\hline zmanjkati komu štrene & 10 & 21 & 23 & \\
\hline gliha vkup štriha & 32 & 13 & 9 & \\
\hline dati si štrik za vrat & 49 & 5 & 0 & \\
\hline kamor je šel bik, naj gre še štrik & 16 & 29 & 9 & \\
\hline imeti tavžente & 10 & 13 & 31 & imeti peneze \\
\hline biti kaj mrzel/hladen tuš & 8 & 10 & 36 & \\
\hline biti ista mera in vaga & 4 & 12 & 38 & \\
\hline kupovati, prodajati na vago & 17 & 18 & 19 & \\
\hline biti kaj na vagi & 11 & 19 & 24 & \\
\hline (dobra) mera in vaga $v$ nebesa pomaga & 5 & 8 & 41 & \\
\hline dati kaj na vago & 45 & 6 & 3 & \\
\hline ne stati/imeti/dati niti vinarja & 4 & 11 & 39 & \\
\hline plačati vse do zadnjega vinarja & 7 & 13 & 34 & \\
\hline gledati na vsak vinar & 9 & 13 & 32 & $\begin{array}{l}\text { gledati na vsak dinar, gledati na } \\
\text { vsak tolar, gledati na vsak evro }\end{array}$ \\
\hline en krivičen vinar deset pravičnih sne & 1 & 7 & 46 & \\
\hline rožnik deževen - vincar reven & 1 & 10 & 43 & \\
\hline na (vse) mile viže & 10 & 8 & 36 & \\
\hline na vsako vižo & 13 & 15 & 26 & \\
\hline biti v zosu & 43 & 9 & 2 & biti v dreku \\
\hline držati žakelj & 22 & 13 & 19 & \\
\hline dati hišo v žakelj & 3 & 7 & 44 & \\
\hline dati koga v žakelj & 13 & 9 & 32 & \\
\hline biti oblečen v žakelj & 26 & 7 & 21 & \\
\hline jemati iz skupnega žaklja & 26 & 13 & 15 & \\
\hline ko je bil žakelj prazen, sta šla narazen & 19 & 13 & 22 & \\
\hline kupiti, vzeti mačka v žaklju & 42 & 9 & 3 & \\
\hline prazen žakelj ne stoji pokonci & 38 & 13 & 3 & prazna vreča ne stoji pokonci \\
\hline soditi/spadati v isti žakelj & 28 & 9 & 17 & $\begin{array}{l}\text { metati } v \text { isti žakelj, spadati } v \text { ist } \\
\text { lonec }\end{array}$ \\
\hline Žakelj brez dna & 27 & 16 & 11 & sod brez dna \\
\hline dobiti žegen za kaj & 29 & 16 & 9 & \\
\hline blažev žegen & 9 & 11 & 34 & \\
\hline poročiti se brez žegna & 13 & 19 & 22 & \\
\hline žlahta je strgana plahta & 26 & 13 & 15 & \\
\hline dober sosed je več vreden kot vsa žlahta & 21 & 16 & 17 & \\
\hline zadeti koga božji žlak & 4 & 9 & 41 & \\
\hline
\end{tabular}




(>>
\begin{tabular}{|l|l|l|l|l|}
\hline Frazem & + & 0 & - & Varianta frazema \\
\hline na (vse) božje/mile/mrtve žlake & 5 & 7 & 42 & \\
\hline vse gre kakor po žnori & 6 & 8 & 40 & vse gre kakor po maslu \\
\hline ne priplavati po (prežgani) župi & 33 & 10 & 11 & ne z lune pasti \\
\hline zakuhati komu (lepo) župo & 35 & 14 & 5 & \\
\hline $\begin{array}{l}\text { nobena župa se ne poje tako vroča, kot } \\
\text { se skuha }\end{array}$ & 45 & 8 & 1 & \\
\hline $\begin{array}{l}\text { kakršno župo si boš skuhal, takšno boš } \\
\text { pojedel }\end{array}$ & 45 & 9 & 0 & kakor si boš postlal, tako boš spal \\
\hline
\end{tabular}

6.2 Rezultati ankete kažejo, da 15,38 \% frazemov z germanizmi uporablja od 75 do 100 \% anketirancev: šparati se pri delu, prava štala, najprej štalca, potem pa kravca, imeti štimo, mešati (komu) štrene, dati si štrik za vrat, dati kaj na vago, kupiti/vzeti mačka v žaklju, prazen žakelj ne stoji pokonci, nobena župa se ne poje tako vroča, kot se skuha.

V korpusu FidaPLUS je potrjenih 90,90 \% navedenih frazemov: prava štala, najprej štalca, potem pa kravca, imeti štimo, mešati (komu) štrene, dati si štrik za vrat, dati kaj na vago, kupiti, vzeti mačka vžaklju, prazen žakelj ne stoji pokonci, nobena župa se ne poje tako vroča, kot se skuha.

Od 50 do $75 \%$ anketirancev uporablja 16,66 \% ponujenih frazemov: šnofati tobak, kdor jezika špara, kruha strada, (biti) kaj drag špas, ne biti za špase, nabirati špeh, prometna špica, gliha vkup štriha, soditi v isti žakelj, žakelj brez dna, dobiti žegen za kaj, ne priplavati po (prežgani) župi, zakuhati komu (lepo) župo.

V korpusu FidaPLUS je potrjenih 84,62 \% navedenih frazemov: kdor jezika špara, kruha strada, (biti) kaj drag špas, nabirati špeh, prometna špica, gliha vkup štriha, soditi $v$ isti žakelj, žakelj brez dna, dobiti žegen za kaj, ne priplavati po (prežgani) župi, zakuhati komu (lepo) župo.

Od 75 do $100 \%$ anketirancev ne pozna naslednjih frazemov $(29,48 \%$ obravnavanih frazemov): nobeno rajžo, krvava rihta, (biti) pokrita rihta, (biti) za v rom, časopisni šlager, gnati vse na špico, iti na špico, špogati si (ostro) pripombo, štanga tobaka, biti v štantu, biti ista mera in vaga, (dobra) mera in vaga v nebesa pomaga, ne stati/imeti/dati niti vinarja, en krivičen vinar deset pravičnih sne, rožnik deževen - vincar reven, dati hišo v žakelj, zadeti koga božji žlak, na (vse) božje/mile/mrtve žlake, vse gre kakor po žnori.

Podatki iz korpusa FidaPLUS kažejo, da je še živih in v rabi 40,90 \% navedenih frazemov: krvava rihta, (biti) pokrita rihta, biti $v$ štantu, (dobra) mera in vaga $v$ nebesa pomaga, stati niti vinarja, rožnik deževen - vincar reven, zadeti koga božji žlak, na (vse) božje, mile, mrtve žlake, vse gre kakor po žnori.

Od 50 do $75 \%$ anketirancev ne pozna 17,95 \% ponujenih frazemov: cela rajda, šlager leta, sezone, biti šlapa, dati, vzeti v štant, imeti tavžente, biti kaj hladen/ mrzel tuš, plačati vse do zadnjega vinarja, gledati na vsak vinar, na (vse) mile viže, na vsako vižo, dati koga vžakelj, blažev žegen. 
V korpusu FidaPLUS je potrjenih 76,92 \% navedenih frazemov: cela rajda, šlager leta, sezone, biti šlapa, dati, vzeti v štant, biti kaj hladen/mrzel tuš, na (vse) mile viže, na vsako vižo, dati koga v žakelj, blažev žegen.

Od 50 do $75 \%$ anketirancev redko oz. pasivno uporablja naslednji frazem in pregovor $(3,80 \%$ obravnavanih frazemov): cel regiment, kamor je šel bik, naj gre še štrik. Oba sta potrjena tudi v korpusu FidaPLUS.

6.3 Zanimalo nas je tudi, katere variante frazemov anketiranci še uporabljajo oziroma katere sestavine so zamenjale germanizme $\mathrm{v}$ pogovornem jeziku mladih, a je zelo malo anketirancev izpolnilo ta del vprašalnika. Največkrat so pripisali vzporednice temle frazemom: biti šlapa - biti pes, biti cucek, biti copata; biti špas - biti hec, biti mala malica; biti drag špas - biti drag hec, biti drag šport; prometna špica - prometna konica; gledati na vsak vinar - gledati na vsak dinar; biti v zosu-biti $v$ dreku.

\section{$7 \quad$ Sklep}

Prehajanje prvin iz jezika v jezik je splošno znano dejstvo. Še posebej to velja, če sta jezika stična, zato je razumljivo, da ima slovenččina v svojem besedju med drugim tudi veliko germanizmov. Na severu je namreč ves čas kulturne in politične zgodovine Slovencev obstajal fizični stik med obema jezikoma, ki ni bil nikoli prekinjen.

S tega stališča je razumljivo, da je SSKJ vključeval tudi besede, po izvoru germanizme, ker jih je raba na podlagi kartotečnega gradiva potrjevala $\mathrm{v}$ dovolj veliki pogostnosti.

Kot kažejo kvalifikatorske oznake, v SSKJ vključeni germanizmi niso vraščeni v knjižno besedje jezika. Največkrat so označeni s stilno-plastnimi kvalifikatorji (76 \%), med njimi pa sta najpogostejša nižje pogovorno (70 \%) in pogovorno (25\%).

V SSKJ redko najdemo frazeme, ki so nezaznamovani, saj naj bi bili kot ekspresivne jezikovne enote označeni tudi v slovarju. Najpogosteje so frazemi označeni s socialnozvrstnimi oznakami (57\%), in sicer s kvalifikatorjem pogovorno (64 \%).

$\mathrm{S}$ primerjavo kvalifikatorskih oznak frazemskih sestavin in frazemov smo ugotovili, da povezava med zaznamovanostjo sestavin in zaznamovanostjo frazema obstaja, saj se kvalifikatorske oznake ujemajo v več kot polovici primerov.

Mogoče je opaziti težnjo, da imajo frazemi s socialnozvrstno sestavino nekoliko višji status od nje (67,86 \%), npr.: nižje pog. štrihati - pog. gliha vkup štriha. Nezaznamovani pa so večinoma samo pregovori, ki vsebujejo germanizem, npr.: nižje pog. šparati - kdor jezika špara, kruha strada; pog. vaga - preg. (dobra) mera in vaga $v$ nebesa pomaga; pog. žlahta - žlahta je strgana plahta.

Rezultati ankete so potrdili pričakovanja. Večina mladih uporablja samo $15 \%$ ponujenih frazemov, kar je zelo majhen delež. Več kot polovica anketirancev $48 \%$ ponujenih frazemov ne pozna, čeprav jih je v korpusu FidaPLUS potrjenih od 50 do $75 \%$. To pomeni, da so frazemi z germanizmi mlajši generaciji vedno slabše poznani. Nemščina ni več prestižni jezik, saj je to vlogo prevzela angleščina, katere 
vpliv je v zadnjem času zelo izrazit na vseh jezikovnih ravninah. Kot kažejo nekatere novejše raziskave, je vpliv posebej močan v leksiki in zato lahko posledično pričakujemo odraz tudi na frazeološki ravni.

\section{Krajšave}

bav. avstr. = bavarsko avstrijsko (bair.-öster. = bairisch-österreichisch)

nar. $=$ narečno $($ mdal. $=$ mundartlich $)$

nvn. = novovisokonemško (nhd. $=$ neuhochdeutsch)

poznosrvn. = poznosrednjevisokonemško $($ spmhd. $=$ spätmittelhochdeutsch)

srvn. $=$ srednjevisokonemško (mhd. $=$ mittelhochdeutsch)

stvn. = starovisokonemško (ahd. = althochdeutsch)

zgodnjenvn. = zgodnjenovovisokonemško (frnhd. = frühneuhochdeutsch)

\section{Viri in literatura}

Arhar 2007 = Špela Arhar, Kaj početi z referenčnim korpusom FidaPLUS (http:// www.fidaplus.net/Info/Info_index.html, pridobljeno 27. 11. 2008).

Bezlaj 1995 = ESSJ III = France Bezlaj, Etimološki slovar slovenskega jezika III: $P-S$, Ljubljana: SAZU - ZRC SAZU (izd.) - Mladinska knjiga (zal.), 1995.

Bezlaj 2005 = ESSJ IV = France Bezlaj, Etimološki slovar slovenskega jezika IV: Š-Ž, Ljubljana: Ljubljana: SAZU - ZRC SAZU (izd.) - Založba ZRC, 2005 (zal.).

ESSJ III $\rightarrow$ Bezlaj 1995

ESSJ IV $\rightarrow$ Bezlaj 2005

$\mathrm{F}+\rightarrow$ FidaPLUS

FidaPLUS = F+= FidaPLUS: korpus slovenskega jezika (http:/www.fidaplus.net).

Gantar 1996/97 = Apolonija Gantar, Skladenjska in pomenskosestavinska tipologija glagolskih in prislovnih rekel, Jezik in slovstvo 42 (1996/97), št. 6, 237-248.

Gantar 2007 = Polona Gantar, Stalne besedne zveze v slovenščini: korpusni pristop, Ljubljana: Založba ZRC, ZRC SAZU, 2007 (Lingua Slovenica 3).

Jakop 2006 = Nataša Jakop, Pragmatična frazeologija, Ljubljana: Založba ZRC, ZRC SAZU, 2006 (Studia linguistica 14).

Ivanetić 2002 = Nada Ivanetić, Germanizmi kao komponente supstandardne frazeologije, Riječ 8 (2002), št. 1, 35-45.

Jazbec 2007 = Helena Jazbec, Nemške izposojenke pri Trubarju na primeru besedila Ena dolga predguvor, Ljubljana: Založba ZRC, ZRC SAZU, 2007.

Jenko 1994 = Elizabeta M. Jenko, Sich auf die Socken machen = Vzeti pot pod noge: deutsch-slowenisches Wörterbuch der Redewendungen: mit einer kontrastiven Studie, Klagenfurt: Drava, 1994.

$\mathrm{K} \rightarrow$ Keber 2003

Keber $2003=\mathrm{K}=$ Janez Keber, Frazeološki slovar slovenskega jezika: poskusni zvezek, Ljubljana: Založba ZRC, ZRC SAZU, 2003. 
Kržišnik 1994 = Erika Kržišnik, Slovenski glagolski frazemi (ob primeru frazemov govorjenja): doktorska disertacija, Ljubljana, 1994.

Kržišnik 1998 = Erika Kržišnik, Socialna zvrstnost in frazeologija, Seminar slovenskega jezika, literature in kulture: zbornik predavanj 34, Ljubljana: Filozofska fakulteta, Oddelek za slovanske jezike in književnosti, 1998, 53-69.

Kržišnik 2004 = Erika Kržišnik, Določanje jezikovno- in/ali besedilnozvrstne zaznamovanosti v frazeologiji, v: Aktualizacija jezikovnozvrstne teorije na Slovenskem: členitev jezikovne resničnosti $=$ Obdobja 22, ur. Erika Kržišnik, Ljubljana: Center za slovenščino kot drugi/tuji jezik pri Oddelku za slovenistiko Filozofske fakultete, 2004, 103-120.

Kržišnik 2005 = Erika Kržišnik, A type of minimal phraseological units characteristic of Slovene, Linguistica, 45 (2005), 159-172.

Majdič 2004 = Viktor Majdič, SSKJ - vedno pri roki, v: Viktor Majdič, Pogledi na jezik: razprave in članki o slovenskem jeziku, Ljubljana: Debora, 2004, $55-79$.

Menac 2007 = Antica Menac, Hrvatska frazeologija, Zagreb: Knjigra, 2007.

SES $\rightarrow$ Snoj 2003

Snoj 2003 = SES = Marko Snoj, Slovenski etimološki slovar, Ljubljana: Modrijan, 2003.

Snoj 2006 = Marko Snoj, O tujkah in izposojenkah v slovenskem jeziku, Slovensko jezikoslovje danes $=$ Slavistična revija54 (2006), posebna številka, 343-350.

SSKJ = Slovar slovenskega knjižnega jezika $z$ Odzadnjim slovarjem slovenskega jezika in Besediščem slovenskega jezika z oblikoslovnimi podatki: elektronska izdaja na plošč CD-ROM, Ljubljana: ZRC SAZU, 2005.

$\mathrm{ST} \rightarrow$ Striedter-Temps 1963

Stramljič Breznik 2004 = Irena Stramljič Breznik, Germanizmi v zahodnem slovenskogoriškem podnarečju, Annales 14 (2004), št. 2, 331-336.

Stramljič Breznik 2007 = Irena Stramljič Breznik, Samostalniški germanizmi v frazemih Slovarja slovenskega knjižnega jezika od A do H, v: Besedje slovenskega jezika, ur. Marko Jesenšek, Maribor: Slavistično društvo, 2007 (Zora 50), 291-303.

Stramljič Breznik 2007a = Irena Stramljič Breznik, Slovensko besedje v prepletu znotraj- in medjezikovnih razmerij, v: Besedoslovne spremembe slovenskega jezika skozi čas in prostor, ur. Marko Jesenšek, Maribor: Slavistično društvo, 2007 (Zora 49), 459-471.

Stramljič Breznik 2009 = Irena Stramljič Breznik, Pomenski opisi rastlinskih poimenovanj v novem slovarju slovenskega jezika, v: Strokovni posvet o novem slovarju slovenskega jezika, ur. Andrej Perdih, Ljubljana: Založba ZRC, ZRC SAZU, 2009, 109-118.

Striedter-Temps $1963=$ ST $=$ Hildegard Striedter-Temps, Deutsche Lehnwörter im Slovenischen, Berlin: Osteuropa-Institut, Wiesbaden: in Kommission bei O. Harrassowitz, 1963.

Toporišič 1973/74 = Jože Toporišič, K izrazju in tipologiji slovenske frazeologije, Jezik in slovstvo 19 (1973/74), št. 8, 273-279. 
Toporišič 1992 = Jože Toporišič, Enciklopedija slovenskega jezika, Ljubljana: Cankarjeva založba, 1992.

Toporišič 1996 = Jože Toporišič, Dvojčiči in podobne frazeološke zgradbe v slovenščini, Slavistična revija 44 (1996), št. 3, 269-279.

Toporišič 2000 = Jože Toporišič, Slovenska slovnica, Maribor: Obzorja, ${ }^{4} 2000$.

Valh Lopert 2007 = Alenka Valh Lopert, Germanismen in der Sprache des kommerziellen Radiosenders Radio City Maribor, v: 10. Arbeitstagung für bayerisch-österreichische Dialektologie an der Alpen-Adria-Universität Klagenfurt, 19. bis 22. September 2007 = Klagenfurter Beiträge zur Sprachwissenschaft 34-36 (v tisku).

\section{Germanisms in idioms in the Slovar slovenskega knjižnega jezika (Standard Slovenian Dictionary) from R to $\breve{Z}$}

\section{Summary}

Native and borrowed elements always coexist in all segments of language, including idioms, especially in cases of language contact, such as Slovenian and German. This article presents the final part of a study $(\mathrm{R}-\breve{Z})$ using the methodology already applied in researching Germanisms that form parts of idioms in the Slovar slovenskega knjižnega jezika (Standard Slovenian Dictionary, SSKJ). Previous parts included A-L and M-P. The contemporary use and knowledge of idioms was assessed using a reference corpus and questionnaire. A total of thirty-eight Germanisms (thirty-four nouns and four verbs) were analyzed.

The dictionary labels indicate that the idioms analyzed are not incorporated in the standard Slovenian lexis because stylistic qualifiers prevail (76\%), the most frequent of which are vulgar colloquial (70\%) and neutral colloquial (25\%).

Comparing the qualifiers of the Germanisms analyzed with the idioms showed a correlation between marked constituents and marked idioms because the qualifiers match in more than $50 \%$ of cases. It may be possible for the idioms with markers denoting social register to hold slightly higher status (neutral colloquial) than the Germanisms (vulgar colloquial); for example, vulgar colloquial strihati 'to paint' vs. neutral colloquial gliha vkup štriha 'birds of a feather flock together' and vulgar colloquial štrik 'rope' vs. neutral colloquial kamor je šel bik, naj gre še štrik 'in for a penny, in for a pound'.

An interview with fifty-four second-year students in the single-discipline undergraduate program in Slovenian at the University of Maribor's Faculty of Arts confirmed the expectations. Most young people use only $15 \%$ of the 72 idioms cited, which is a very low share. More than half of the survey respondents were not familiar with the idioms, although they are confirmed by the FidaPLUS reference corpus. It can be concluded that idioms with Germanisms are less known to the younger generation because most of them are studying English as their first foreign language. German has lost its prestigious status as a result of social and economic changes; its role has been supplanted by English. 